This is an Accepted Manuscript of an article published by Taylor \& Francis in Ethnos (2016), available online: http://www.tandfonline.com/doi/full/10.1080/00141844.2015.1084016.

\title{
Buddhist Vegetarian Restaurants and the Changing Meanings of Meat in Urban China
}

Jakob A. Klein

SOAS, University of London

\begin{abstract}
This article charts the changing meanings of meat in contemporary urban China and explores the role played by Buddhist vegetarian restaurants in shaping these changes. In Kunming, meat has long been a sign of prosperity and status. Its accessibility marked the successes of the economic reforms. Yet Kunmingers were increasingly concerned about excessive meat consumption and about the safety and quality of the meat supply. Buddhist vegetarian restaurants provided spaces where people could share meat-free meals and discuss and develop their concerns about meat-eating. While similar to and influenced by secular, Western vegetarianisms, the central role of Buddhism was reflected in discourses on karmic retribution for taking life and in a non-confrontational approach that sought to accommodate these discourses with the importance of meat in Chinese social life. Furthermore, the vegetarian restaurants spoke to middle-class projects of self-cultivation, and by doing so potentially challenged associations between meat-eating and social status.
\end{abstract}

[China, Buddhism, vegetarianism, meat, restaurants] 
In recent years, vegetarian restaurants have been flourishing in mainland Chinese cities. A major new report on China's food system found over 50 vegetarian restaurants each in Guangzhou, Shanghai and Beijing (Garnett \& Wilkes 2014:96). Journalists claimed in 2012 that there were 'nearly 100' vegetarian eating places in Beijing, compared to 'only two' fifteen years earlier (Marsh \& Hale 2012).

The aforementioned food system report classifies the majority of the vegetarian establishments as 'Buddhist' (Garnett \& Wilkes 2014:96), suggesting links to China's long history of Buddhist vegetarianism (Kieschnick 2005; Cao 2010). Indeed, while openly Buddhist practices were severely constrained during the radical socialist years of the 1950s1970s, a religious resurgence beginning in the 1980s has on some accounts spurred on the demand for vegetarian fare, not least among the growing urban middle class (Goosaert \& Palmer 2011:283; Fan et al. 2005).

Yet despite the large number of vegetarian establishments in the major cities described as 'Buddhist', several journalists argue that vegetarian eating has become a lifestyle choice among young, affluent, educated urbanites concerned not so much with religion but about their bodily health, especially in the wake of food safety scandals (Tang 2008; Nelson 2011; Marsh \& Hale 2012). Some Chinese vegetarian writers similarly downplay the role of Buddhism in China's contemporary vegetarianism. Shi Youbo (2004) and Guo Geng (2003) identify themselves as part of a 'new wave vegetarianism' (xin chao sushizhuyi). They pay homage to Buddhist and other Chinese traditions of meat avoidance, yet depict the new vegetarianism as a secular, health-oriented, modern and international lifestyle choice developing on China's university campuses rather than through its monasteries. Shi and Guo emphasise the ethical dimensions of the new vegetarianism. Invoking the authority of science rather than religion, they claim inspiration from transnational environmentalist and animal rights discourses that connect contemporary meat 
production to the destruction of ecosystems and global warming, cruelty to animals, food insecurity, and unsafe foods and other public health problems.

Other Chinese writers on vegetarianism, the philosophers Cao Wenbin (2010) and Chen Hongbing (2009), insist on the centrality of Buddhism in contemporary Chinese vegetarianism, while encouraging Buddhists to engage with science-oriented and other secular vegetarian discourses. According to Chen, Buddhists should embrace these in order to make themselves more relevant to contemporary society. Cao, meanwhile, develops an ethics that draws on the arguments of Peter Singer's animal liberation philosophy but which is underpinned by the religious beliefs of Chinese Buddhism. Although Cao and Chen do not mention it, in Taiwan 'humanistic' Buddhist groups have for decades been engaging with Western environmentalisms (Weller 2006:127). And as sociologists of Chinese religion (Goosaert \& Palmer 2011) and the ethnography I will present here indicate, this engagement is also occurring in many Buddhist vegetarian restaurants in the contemporary urban PRC, in some cases with Taiwanese connections in the context of an ever-more globalised Chinese Buddhism (Ashiwa \& Wank 2005).

Clearly, as with vegetarianisms elsewhere (Avieli 2014; Beardsworth \& Keil 1997:226-232; Boyle 2011), contemporary Chinese meat avoidance involves diverse justifications. Yet in many contexts vegetarians are loosely connected through ideologies, institutions and practices, which set them apart from dominant orientations toward meat (Maurer 2002; Twigg 1983). In urban China, as I argue here, religious resurgence is not a sufficient explanation for the growing popularity of vegetarian fare, but Buddhist eating places do often play an important part in shaping vegetarian practices and discourses and their relationship to more mainstream Chinese foodways. 
My discussion is indebted to Goosaert \& Palmer (2011:271-313), who suggest that the diversity of vegetarian motivations is in fact indicative of the religious culture of contemporary Chinese cities: in a highly secularised environment with 'weakened or nonexistent communal religious institutions' (2011:286), persons seeking moral guidance have been left to their own devices to combine practices and discourses from a variety of sources. In this context, Buddhist restaurants have 'served as a meeting point for people in search of moral norms and ethical living' (2011:285-86).

Goosaert \& Palmer argue that while contemporary Chinese urban vegetarian groups speak to current issues such as food safety and dietary health, they also serve as conduits of knowledge about traditional Chinese purity rules (zhaijie) centring on meat avoidance, and about the religious and moral beliefs indexed by these rules. As such, contemporary vegetarianism in China can be seen as an engagement with a historically longstanding moral ambivalence surrounding the taking of animal life for human consumption. According to Goosaert \& Palmer these once widespread moral concerns became muted in the twentieth century as a consequence of the promotion of meat by modernising elites and states intent on undermining 'superstitious' qualms about taking animal lives in favour of a 'scientific', nutrition-based approach to strengthening Chinese bodies. Against this background, the renewed interest in vegetarianism is on Goosaert \& Palmer's account 'one of the strongest expressions of the contemporary reformulation of traditional morality in China' (2011:285).

Building on Goosaert \& Palmer's insights, I approach Buddhist vegetarian restaurateurs and their customers as actors engaged in redefining moral norms and ethical practice in a China where the communist Party-State, once an intimate presence in people's lives that enforced a morality of collectivism, frugality and self-sacrifice, increasingly rules 'from afar' while promoting self-reliance and self-development, leaving greater space for citizens to work out for themselves how to live their lives (Ong \& Zhang 2008; Kleinman et 
al. 2012). Further, in an increasingly stratified society, the ability to display self-development and cultivation has become an important measure of the human 'quality' (suzhi) deemed necessary to establish one's membership in the urban middle class (Zhang 2008). The vegetarian activist-entrepreneurs and the often middle-class eaters discussed here addressed questions of how to live one's life by pursuing an ethics of eating that centred on the nurturance of health and the cultivation of bodily discipline, often articulating these healthoriented bodily practices with transnational discourses and global concerns as well as with longstanding Chinese moral beliefs and practices.

Unlike Goosaert \& Palmer, who discuss Buddhist vegetarianism in relation to contemporary Chinese religion, the focus of my investigation is on the relationship between vegetarian restaurants and the changing meanings of meat in Chinese society. In line with a core theme of this special issue I explore ethnographically the relationship between an industrialising food supply system and the uses and understandings of animals-as-food in a specific cultural context. In what ways do Buddhist vegetarian restaurants engage with and perhaps influence wider urban Chinese approaches to meat?

Scholars of food in Euro-American societies have drawn connections between the growth of 'anxieties' surrounding industrialised foods and the spread of vegetarianism (Beardsworth \& Keil 1997:236-40; Ashley et al. 2004:187-203; Fiddes 1991). As these scholars point out, regulating one's intake of food may be a way for individuals to exercise control, and meat is often seen to be particularly prone to carrying polluting substances. An emphasis on bodily self-control may lead to an awareness of the questions surrounding the raising and slaughtering of animals, not least as vegetarian organisations often emphasise the individual health benefits of avoiding meat when recruiting, and subsequently encourage people to adopt a broader, 'ethical' stance on vegetarianism (Maurer 2002). 
In Western countries, restaurants and cafes have provided spaces for vegans, vegetarians and others to socialise and discuss the ethics of eating, and have contributed to an infrastructure supporting alternative or oppositional food movements (Clark 2004; Belasco 2005). By facilitating vegetarian dining and commensality between vegetarians and meat eaters, the restaurant and food industries have also contributed to the 'mainstreaming' of vegetarianism in the sense both of a growing popularity of meat avoidance and acceptance of it among meat eaters but also of a diluting of some of vegetarianism's potential to critique dominant social norms and the food system (Maurer 2002; Belasco 2005; Beardsworth \& Keil 1997:239-240; Morris and Kirwan 2012). With vegetarianism becoming an acceptable, and often flexible, lifestyle choice, the vegetarian movement has become rife with tensions between those endorsing this popularisation and those insisting on a more absolutist approach to the rejection of animal foods (Maurer 2002; Morris \& Kirwan 2012).

Yet, with some notable exceptions (Staples 2008; this issue; Avieli 2014), where it comes to historically 'meat poor' parts of the world social scientists have shown little interest in individual vegetarians or in the role of restaurants, the food industries and social movements in shaping their beliefs and practices. This neglect appears to stem from a distinction made between Western 'voluntary' vegetarianism and 'cultural' or 'povertyimposed' vegetarianism elsewhere (Klein 2008). This always problematic distinction is still reiterated in the literature (e.g., Morris \& Kirwan 2012:545), but it has become increasingly untenable against the backdrop of the growing availability of meat in many previously 'meatpoor' parts of the world.

Clearly, a more comprehensive understanding of vegetarian movements and their relationship to industrialising food systems and to mainstream cultural understandings surrounding the use of animals-as-food will have to pay serious attention to "voluntary vegetarianisms' in non-Western contexts. Such vegetarian movements are emerging within 
cultural milieus where approaches to killing animals for food may be very different from those assumed in studies of Western vegetarianism. In Western contexts, vegetarian movements have challenged a powerful ontological separation between humans and animals underpinning the legitimisation of killing for food (Valeri 2000:179-180), and it is noteworthy that these movements have often looked for inspiration to Hindu philosophical traditions, where this separation is absent (Stuart 2006; Hurn, this issue). Of course, this ontological separation is not a precondition for eating meat (Valeri 2000). In China, the culinary and ritual importance of meat has historically coexisted with an approach to humananimal relations that does not categorically distinguish between the two. While modernisers have attempted to instil a much a sharper division between humans and non-human animals, Buddhist traditions in particular serve as a reminder of a different indigenous ontology.

In what ways do growing access to meat and an industrialising food system, memories of recent meat poverty and radical socialism, the centrality of meat in social life, a growing middle class and a resurgent Buddhist vegetarianism come together to shape contemporary urban Chinese approaches to meat eating? What is the significance of China's vegetarian movement for our understanding of voluntary vegetarianism in comparative perspective?

My discussion is based on fieldwork I carried out in Kunming, the capital of Yunnan Province in southwest China. Often considered to be 'lagging behind' China's major eastern seaboard cities, since the late 1990s Kunming has undergone a massive redevelopment and has emerged as a hub of regional trade and tourism. With a population of at least three million - twice that of the early 1990s - the city has grown in both size and social complexity, as more migrants from the countryside arrive and as protected, 'garden-style' residential complexes are built for members of the growing professional middle class, setting them apart from those on lower incomes living in the city's simpler housing developments (Zhang 2008). 
Fieldwork on vegetarian restaurants was conducted as part of wider research into food consumption, cuisine and food-related social activism, which I carried out in Kunming for six months between 2006 and 2012. Research included observations and conversations in and around the city at restaurants, markets, shops, farms, food businesses, activist groups and government offices. Between 2008 and 2012, I paid multiple visits to a vegetarian centre called Sino-Agriculture. Interviews were conducted in 2012 at the other three vegetarian establishments described here. The discussion of changing attitudes to meat draws heavily on interviews on food shopping, cooking and eating conducted in 2008 and 2009 with members of 25 Kunming households. Households were identified through previous contacts and snowballing. Roughly half of the households could be described as middle class. Other households interviewed included migrant workers and native Kunming workers, shopkeepers and poor pensioners.

\section{Chinese Buddhist Vegetarianism and the Problem of Meat}

Arguments for meat avoidance among Chinese Buddhists have typically involved notions of 'karmic retribution' (ebao) and the 'protection of life' (husheng) (Cao 2010). Eating meat is seen to make one complicit in the 'killing of life' (shasheng), an act which incurs retribution since the 'Buddha nature' (foxing) - the potential to end the cycle of death and rebirth - resides in and connects 'all living beings' (zhongsheng) (Cao 2010:50-53; Xu \& Xu 2007). Conversely, karmic merit (gongde) can be accrued through acts of compassion (cishan) for other living beings. Moreover, meat and alcohol are believed to arouse people's desires, as are certain condiments, including onion, garlic and Chinese chives (jiucai). The latter are classified as 'small meats' (xiaohun) and like alcohol are avoided by those observing a strict Buddhist diet. 
Buddhist vegetarianism and sanctions against taking life have long played a part in Chinese popular culture. In late imperial times, 'releasing life' (fangsheng) - the practice of liberating animals from captivity to gain merit - became established among the upper strata of society (Handlin Smith 1998). This was being practised among some lay Buddhists I met in Kunming, who occasionally would purchase live animals from the food markets in order to set them free. Fan et al. (2005:56) similarly report on fangsheng outings organised by a group of lay Buddhists associated with a vegetarian restaurant in Shenzhen. Chinese lay Buddhists have typically not been expected to maintain strict vegetarian diets, but to abstain from meat and observe other purity rules on certain days, and particularly on the first and fifteenth of each lunar month (chuyi-shiwu), the key days for visiting temples (Cao 2010:95-96).

Especially from the Song Dynasty $\left(10^{\text {th }}-13^{\text {th }}\right.$ centuries $)$, a complex vegetarian cuisine developed, catering not least for lay Buddhist pilgrims and other worshippers at Buddhist temples. This cuisine centres on 'mock meat' (fanghun) dishes that are meant to capture the flavour and texture of meats with the use of substitutes such as wheat gluten, soybeans and mushrooms (Kieschnick 2005; Cao 2010:94-95).

Yet although abstention from meat in Chinese contexts has often been associated with Buddhism, vegetarianism as orthodoxy among Chinese Buddhist monks and nuns was established only by the tenth century, several centuries after the introduction of Buddhism into China (Kieschnick 2005). Indeed, the adoption of vegetarianism within Chinese Buddhism was part of a wider moral unease about killing animals for food that predates the arrival of Buddhism and which is shared with other religious and philosophical traditions, including Confucianism and Daoism (Cao 2010:18-31). Not least, the association in China between copious meat-eating and immoral excess long predates the arrival of Buddhism and was according to Kieschnick (2005) an important factor behind the eventual adoption of 
vegetarianism among Chinese Buddhists. Suggestively, the most common term for vegetarian food, sushi, is most literally translated as 'simple' or 'plain' food.

Yet while the taking of life raises moral concerns, animal flesh is also vital to Chinese religious and social life. Highly praised for its flavours and textures and, if not eaten to excess, its medicinal values to the human body (Anderson 1988:229-243), it is also seen as an ideal mediator between people and crucial to festive meals and banquets, particularly at life-cycle and annual rituals (Watson 2014). It is no less important as sustenance for ancestors and other supernatural beings: sacrifices of meat are fundamental to the relationships of reciprocity constructed between the living and the dead (Thompson 1988; Goosaert 2005b; Watson 2014). Chinese have thus faced a cross-culturally widespread dilemma discussed in the introduction to this special issue: meat is a powerful substance, yet its existence depends upon - and much of its power is seen to derive from - the killing of living beings with whom we share fundamental characteristics (Valeri 2000). Particularly problematic has been the eating of flesh of animals with whom humans have developed intimate relationships, such as bovines in China, who as draught animals during late imperial times came to be regarded as 'work companions' in agriculture (Goosaert 2005a:241; 2005b: chapter two) - not unlike views expressed by Staples's South Indian farmers (this issue) and at Hurn's Welsh ashram (this issue).

In many cultural contexts attempts are made to regulate the moral dangers of meat through complex systems of taboo (Valeri 2000). In China, as Goosaert (2005b: chapter one) discusses, sacrifices of animal flesh have often been preceded by the observance of purification rules. Goosaert $(2005 a ; 2005 b)$ further argues that the once widespread beef taboo in China was an attempt to resolve the tension between the immorality of meat and its ritual and social necessity. Complete abstinence from meat would undermine the sacrificial and commensal practices on which communities depended, and was widely frowned upon 
when taken up by laypeople. But the avoidance of certain meats was a recognition of the moral dilemma. Indeed, the practice of periodic observances of purity rules or fasting and short-term pledges of vegetarianism or 'releasing life' among Buddhist laypeople could be interpreted in a similar vein (Goosaert 2005a:240). Meat could and should be eaten - but not all meats, not at all times and not to excess.

As we shall see in the next section, many of these themes are highly relevant in contemporary China. In Kunming, most people I met ate animal flesh on a daily basis and meat was widely regarded as an important part of shared meals, especially on festive occasions. The use of meat as sacrifice to ancestors was not mentioned to me by informants who had grown up in the city, but the practice remains significant in rural areas (Oxfeld 2014:60). Yet despite the pro-meat ideologies of modern Chinese states and the dramatically improved access to meat during the last three decades, even regular meat-eaters in Kunming were increasingly raising concerns about meat, concerns which I will suggest implicitly invoked longstanding but largely dormant moral qualms about the taking of animal life for human consumption, and which were also explicitly being articulated with such qualms in Kunming's new vegetarian restaurants.

\section{Meat-eating in Kunming}

In 1980, according to FAO figures, average annual per capita meat consumption in China stood at $13.7 \mathrm{~kg}$ (FAO 2009:11). By 2005 it had more than quadrupled to $59.5 \mathrm{~kg}$, lower than in the UK $(83.9 \mathrm{~kg})$ or the US $(126.6 \mathrm{~kg})$ that year, but higher than in Russia $(52.1$ $\mathrm{kg})(2009: 135-136)$. For hundreds of millions of Chinese, animal flesh has been transformed from a luxury good to an everyday food (Gale and Huang 2007). The growing intake of animal flesh has been made possible not only by rising real incomes (Ash 2006), but also by the intensification of livestock production. While observers have highlighted the implications 
of China's increased production and consumption of meat for public health and the environment (Schneider 2011; Garnett \& Wilkes 2014), less attention has been paid to its meanings for Chinese eaters.

For most Kunmingers, with the important exception of the city's Hui Muslim minority, 'meat' (rou) meant especially pork. As elsewhere in South China (Watson 2014), pork has been crucial to marking festivals and life-cycle events, standing in contrast to largely meat-free daily meals. Traditional banquets in the region, served at weddings and other special occasions, were known as the 'eight bowls of pork' (zhubawan) (Yang 2006:139-140). Elite families would add more scarce animal foods to their festive meals. The late Mr Yang, an informant born in Kunming in the 1920s, grew up in a well-to-do merchant family. He claimed that before communist Liberation the wealthy in this land-locked region looked down on these pork banquets and would distinguish themselves through the addition of dried seafood such as shark's fins and sea cucumber imported from outside the province.

This pattern of meat-sparse daily meals interrupted by festivals centring on animal foods continued during the Mao era of the 1950s-1970s. Acquaintances who were old enough to remember this period often described it as one of meat deprivation. Pork, especially fresh pork, was limited and seasonal. Auntie Liu, a retired textile worker, explained to me that during her youth in the 1960s meat had been strictly rationed. For most of the year her family ate bean curd instead. She recalled with great fondness the pork dishes they prepared at home at the Chinese New Year, when her father's work unit would slaughter pigs for its employees: red-braised pork (hongshaorou), pork steamed with rice meal (fenzhengrou), and twicecooked pork (huiguorou).

The movement from meat-scarce to meat-rich diets played a key part in Kunmingers' narratives of transition from the poverty associated with radical socialism to the greater affluence of the reform era. Master Liu (no relation to Auntie Liu), had worked as a cook in 
some of the city's foremost state-run restaurants in the 1970s and early 1980s. He explained that at that time he and his colleagues would ironically speak of the 'three great famous dishes' (san da mingcai) of the state-run restaurants: red-braised pork, stir-fried pork mince (chao duorou) and twice-cooked pork. The irony was that these were in fact uncomplicated, family-style dishes. Master Liu explained that everyone had been used to rationing. As long as there was lots of meat on the table they were happy with simple preparations. But increasingly, as meat became more common, customers began demanding more refined delicacies. Business became difficult for the state-run restaurants, he explained, as people turned to the more innovative, privately run establishments. Master Liu exclaimed: 'It used to be that we ate meat only at the Chinese New Year. But now every day is like celebrating New Year!'

In these accounts, the current abundance of meat is not unambiguously positive. Both suggest that meat-eating had been more meaningful when access to animal flesh was limited. In Master Liu's account there is the sense that meat-eating had become excessive. A link between meat-eating and excess was often made by Kunmingers. In some contexts it was the perceived health effects of this excess that were highlighted. Master Liu claimed that he had drastically reduced his consumption of meat about ten years earlier, after suffering from high blood pressure and depression. Another informant, a generation older than Master Liu, explained that because meat was so uncommon when he was growing up, unlike his grandchildren he was not able to regularly eat meat, as he had difficulties digesting it. Others claimed that this embodied legacy of meat poverty was widespread among the elderly.

Often, the excessive consumption of animal foods also took on connotations of immorality. Corrupt officials were described as consuming 'great amounts of fish and meat' (dayu-darou), and some people used this same expression to describe the current period as one of wastefulness and indulgence, sometimes in explicit contrast to the ethics of frugality 
dominant during the Maoist period (cf. Farquhar 2002). For those Kunmingers who had experienced the radical socialist years, the current availability of meat was a marker of transition to an era of abundance. Yet this abundance, while celebrated, was also problematic to many, in ways that arguably articulated with a long-standing Chinese unease about excessive meat-eating.

The ambivalence toward meat was further compounded by recent concerns surrounding the quality of meat, particularly of pork and chicken. It was widely argued that the quality of meat in the city's markets - in terms of its flavour, texture, healthiness and safety - had deteriorated since the mid-1990s. This was blamed on intensified methods of meat production. Some interviewees mentioned that pork was now often injected with water in order to increase its weight. Others claimed that the use of growth hormones, antibiotics and other chemicals were causing both cancers and unnatural sexual development in adolescents, including, in the words of one female informant in her twenties, 'girls who could no longer be distinguished from boys'. Another young woman explained that the meat now is not healthy because the animals grow too quickly: 'Especially the broilers (rouji) - you can't eat those at all!'

Many discussions about the deterioration of meat quality revolved around distrust of processed feed. Ms Wang, a retired elementary school teacher who ran a small shop in a working-class neighbourhood, remarked: 'Pork used to be so fragrant. The pork now is not nice. Pigs used to be fed on just grain and stalks, now they use processed feed (siliao).' A number of acquaintances described what they called 'feed eggs' (siliao dan) and 'feed chickens' (siliao ji) as 'tasteless'. Pork from 'feed pigs' (siliao zhu) was said to have a bad texture or 'mouth feel' (kougan) and to have a 'fishy' stench (xingwei).

As with the quantity of meat consumed, its quality could also take on moral dimensions. Ms $\mathrm{Wu}$, a retired accountant, drew a parallel between diminishing food quality 
and what she perceived to be a deterioration of social relations and trust in the city, echoing the point made by the anthropologist Yunxiang Yan (2012) that China's recent food safety scandals indexed a wider decline in social trust. In Ms Wu's words: 'People don't behave like human beings [literally, 'don't have the flavour of human feelings']; vegetables don't taste like vegetables; meat doesn't taste like meat' (Ren meiyou renqingwei, cai meiyou caiwei, rou meiyou rouwei).

Kunmingers enjoyed the flavour of animal flesh and its ability to provide sustenance to the human body and to bind people together. Yet growing concerns about the quality of meat raised questions about its efficacy in sustaining individual and social bodies. Bad flavours signalled perceptions of wider problems in the transformation from live animal to meat as a result of new, intensified methods of production, described by many as being 'unnatural' (bu ziran). As with the issue of excessive consumption, the problems of meat quality were at once embedded in concerns about the wider social and moral order, and experienced through the body as bad tastes and smells, as symptoms of ill-health, and as fears of disease.

Concerns about the meat supply were universal among my Kunming informants. Yet people acted on these in different ways, and in some cases the tactics people adopted were clearly influenced by factors such as income, whether they had been raised in the city or had rural origins, and whether they aspired to middle-class status (Klein 2013a). Tactics people claimed to deploy included eating less meat or different kinds of meat. Ms Wang, the shopkeeper, told me that she and her family now ate very little pork. Others claimed that they were instead eating more beef and goat meat since they believed that cows and goats were raised on grass rather than processed feed. Hui Muslim butchers were benefitting from this, not only as purveyors of beef and goat but because many Han Kunmingers perceived Hui meats to be safer than those of other butchers. Some Hui butchers were claiming that their 
meat was both qingzhen (a term which encompasses 'halal' and literally translates as 'pure and true'; see Gillette 2000) and 'ecological' (shengtai). It was even alleged by vendors I met in one of the city's largest food markets that some of the supposedly Hui Muslim butchers in the market were pretending to be Hui to attract Han customers in search of 'safer' meat.

In some cases food safety fears had contributed to radical changes in Kunmingers' eating habits. Freshwater fish from local streams and nearby Lake Dian were once an important part of local cuisine, but were now widely avoided because of fears of industrial pollution. In the 1980s and 1990s visitors to the city were encouraged to try specialities such as stewed bear's paw, stewed elephant trunk and shallow-fried venison tendon (Klein 2013b:210). But game was no longer readily available in Kunming, a consequence not only of wildlife protection legislation since the 1990s but also of the SARS epidemic of 2003, which was widely blamed on the farming of 'wild' civet cats. Once a marker of privilege, as in other Chinese cities consuming game was increasingly seen as an 'uncivilised' practice and avoided by the urban middle class (Zhan 2008). 'Wild foods' (yewei) restaurants in Kunming served a variety of fungi, foraged plants and insects, but no longer advertised the flesh of wild mammals.

Some migrants from the countryside I knew bought little or no pork in the city, relying instead on supplies of smoked and cured meats from their home villages. Wealthier informants were often willing to pay a premium on pork from speciality butchers selling ecologically certified meat. Some urban Kunmingers were sourcing food directly from smallscale producers in the surrounding countryside (Klein 2013a; 2014). Some would get together with friends to order an entire 'New Year's pig' (nianzhu) in advance from a known farmer. Many more sought out rural markets to buy meat from the farmers, instead of from the middlemen who dominated the Kunming markets. Car owners could access quite remote markets - the remoteness and poverty an area being for many signs of more 'natural', less 
industrialised foods (Klein 2014). But some rural and peri-urban markets were accessible by public transportation - and a few even by bicycle - and at the weekends these were visited by throngs of Kunmingers of various economic means. For many, visits to rural markets combined having fun with sourcing more trusted foods. Similarly, since around 2000 Kunmingers, like urbanites elsewhere in China, had taken to visiting nongjiale - farmhouses that had set up facilities for tourists - where they would fish, pick fruits and berries, play mah-jong and eat local foods cooked for them on the farm. Informants described these farmhouse foods as 'simple' and 'natural', healthier than foods available in the city (Klein 2014:127).

Meat remained an important part of everyday diets and festive meals, and to many it was an important signifier of affluence and of the successes of economic reforms. While Kunmingers I interviewed were claiming to change their meat buying or eating habits in response to their worries about overconsumption or the quality of the meat supply, few were prepared to renounce animal flesh. Yet some were taking an interest in meat-free foods and had visited the city's new vegetarian restaurants.

\section{Buddhist Vegetarian Restaurants in Kunming}

This section provides an overview of Kunming's emerging vegetarian movement, exploring how restaurants differed in terms of the kinds of customers they tried to attract and the extent to which they sought to educate diners. In 2012, I counted fifteen vegetarian establishments in the city. This does not include the simple canteens and snack shops in the Buddhist temples, or the unregistered establishments that a few people ran surreptitiously from their own homes. While there had been at least one vegetarian restaurant in Kunming in the 1990s, all of the registered restaurants currently in operation had opened since 2000. Several were situated in the city centre near Yuantong Temple, Kunming's foremost 
Buddhist temple. Others were located around up-market residential neighbourhoods on the outskirts of central Kunming, where they catered to businesses and middle-class residents.

Nearly all of Kunming's vegetarian restaurants emphasised Buddhist connections or inspiration, but they often differed from each other in style. Some, such as Yuquanzhai, were more commercially-oriented. I interviewed the owner-manager, Mr Xiong, in 2012. He claimed that when he founded Yuquanzhai in 2000 there were no other vegetarian restaurants in the city. The restaurant, which seated around 300 customers, was located just outside Yuantong Temple. Next to the restaurant was an outlet of Xiong's chain of vegetarian convenience stores. The store specialised in packaged ready-made mock-meat foods, including 'roast duck' and 'spare ribs'.

Xiong made no attempt to conceal that he was motivated predominantly by profit. Other Buddhist vegetarian restaurants, including Xianghaiyue, Baihe Tianxin (The Green Garden Vegetarian Restaurant) and Zhong Nong (Sino-Agriculture), had pedagogical agendas. These places were smaller than Yuquanzhai and offered, in addition to meat-free food, spaces for contemplation and discussion. Staff cultivated ties with customers and distributed free literature and DVDs on vegetarianism and Buddhism, and some customers brought their own Buddhist pamphlets, which they circulated to other visitors.

Xianghaiyue opened in 2009 within easy walking distance of Yuantong Temple. It was somewhat hidden away on the first floor of an office block, in a quiet location overlooking Panlong River. It was both a teahouse and a restaurant, and customers could while away an afternoon chatting or reading.

The Green Garden ran two restaurants, the first of which opened in 2011. The company was managed by a committee of volunteers and profits went to a charitable trust. It had connections with the state-affiliated Yunnan Province Buddhist Association. The two restaurants distributed pro-vegetarian pamphlets and Buddhist texts endorsed by the 
Association. In the downtown restaurant customers were encouraged to commit to vegetarian diets for different lengths of time and to paste their vegetarian pledges on the wall. Instead of mock-meat dishes, Green Garden emphasised fresh green vegetables and local flavours. It served Yunnanese-style vegetable and bean curd dishes, including vegetarian rice noodles (mixian) and an upmarket version of Kunming-style hotpot (shuancai). It combined the message of vegetarianism with chemical-free farming, and sourced its 'ecological vegetables' from a nearby monastery.

Like Green Garden, the Taiwanese-run Sino-Agriculture (Zhongnong) combined vegetarianism, Buddhism and ecological foods. In 2008 Sino-Agriculture opened an organic vegetarian centre in downtown Kunming. The centre consisted of a restaurant, a café and a food shop, all partly supplied by the company's certified organic farm north of the city. It encouraged regular customers to become members and organised activities for them, including seminars and farm visits.

Kunming's vegetarian restaurants were frequented by a variety of customers, including elderly and young lay Buddhists, professionals, resident foreigners and local, middle-class families. None of these restaurants was exclusively priced, but most were not affordable to lower-income households. An exception was Yuquanzhai. With its conventional 'mock meat' vegetarian fare and relatively low prices, it was the most 'massified' (dazhonghua) of the establishments mentioned here. It attracted temple-goers, many of them elderly. Some of my younger, educated informants expressed a dislike for its food and style. One acquaintance associated the place with dodgy traders who twice a month would visit Yuantong Temple and have a vegetarian meal to compensate for their morally questionable business practices, a claim reminiscent of critiques of vegetarians reported from Vietnam by Avieli (2014). 
By contrast, the other establishments targeted a more up-market and self-consciously 'refined' clientele. The settings were comfortable, quiet and alcohol-free. A consultant working with Xianghaiyue told me that they sought to create 'ambiance' (qifen) rather than the 'hot and noisy' (renao) atmosphere typical of many Chinese restaurants. Staff at SinoAgriculture described the majority of their regular members as well-off Kunming families and young professionals, including people working for environmental NGOs.

As in some of Beijing's trendy new vegetarian restaurants (Nelson 2011), foods at Green Garden and Sino-Agriculture were fresh, healthy and 'organic', often deviating from conventional 'mock-meat' dishes and emphasising the 'natural flavours' of vegetables. While Green Garden distinguished itself by embracing local cuisine, Sino-Agriculture instead presented itself as cosmopolitan. Its shop was stocked with expensive organic goods from Taiwan and Hong Kong. The menu, which listed nutritional information for each item, included 'Korean-style' mushroom soups, 'Japanese' buckwheat noodles, 'New Zealandstyle' mashed potatoes and dishes such as mixed salads and lettuce leaves stuffed with vegetarian mince, un-Chinese in that they featured raw vegetables.

Thus, as in the major cities of eastern China, many of Kunming's vegetarian restaurants catered to the self-consciously refined and cosmopolitan tastes of the new middle class, membership in which was increasingly being defined by lifestyle, taste, healthconsciousness and social conduct (Zhang 2008). As will become clear in the following sections, customers were attracted to these restaurants by a desire to find solutions to their questions about dietary health and meat production, and in some cases also to cultivate middle-class sensibilities for themselves and their children. For their part, restaurant staff encouraged customers not only to commit to vegetarian diets, but also to extend their interests in health and the body to a wide range of ethical questions surrounding the killing of 
animals for food. The following section explores attempts to educate consumers at one of the restaurants, Sino-Agriculture.

\section{Educating Consumers}

Unlike in Hoi An in neighbouring Vietnam (Avieli 2014), in Kunming vegetarian restaurants were not usually regarded by residents as politically subversive. Nevertheless, the education of customers at Kunming's vegetarian restaurants had to comply with state restrictions on explicit proselytising and on religious activities outside of officially sanctioned spaces (Ji 2011). As the manager of Sino-Agriculture explained to me, they did not attempt to convert people to Buddhism. Instead, encouraging vegetarianism and organic farming was a means of spreading 'compassion' (cishan) and 'virtue' (daode). These were in his view acts that could help save the world, the current state of which was a consequence of past human action.

As a Taiwanese organisation Sino-Agriculture had to be especially careful to not appear to be proselytising. In Taiwan, the company went under the name of Li-Ren and was closely linked with the humanistic Buddhist group, Compassionate Heart (Cixin or Tse-Xin). In Kunming, most employees I met described themselves as Buddhists and the restaurant sported a statue of the Bodhisattva Guanyin and played recordings of Buddhist music. Yet it did not distribute any Buddhist literature or spread explicitly Buddhist messages in the classes and other activities it held for members.

The language of Confucianism was now acceptable in the PRC, however, and as part of Sino-Agriculture's attempts to improve social morality it held classes in the Confucian classics for centre members and their children. Children were taught separately from their parents and grandparents. The children's class would focus on joint readings of Confucian primers, and conclude with a visit to the restaurant, where children would eat together with 
the volunteer teachers and be taught good table manners, with a stress on traditional virtues of deference to others and respect for their elders.

Three parents I spoke with after a class lived in some of Kunming's most up-market areas. They were not Buddhists, but sent their singleton children to Sino-Agriculture's classes because they wanted their children to learn proper conduct in order to be successful in the world. For them and other Sino-Agriculture members I knew, membership was part of a cultivation of middle-class sensibilities. Members were engaged in a range of lifestyle practices or consumption choices relevant to the improvement of health, taste and the body. These included purchasing 'organic' foods, taking classes in tea connoisseurship and even engaging private dieticians.

The adult classes at Sino-Agriculture began with joint readings of Confucian texts, but consisted in the main of a lecture on vegetarianism or organics followed by a discussion. Similar classes, but without readings of Confucian texts, were also held for new members. The lectures at all these events tended to follow a similar format, beginning with the negative impact of meat or agrichemicals on eaters' health and the nutritional benefits of a vegetarian diet, and gradually bringing in issues such as the impact of factory farming on animal welfare, water pollution and climate change. The language was largely science-based and lectures often included snippets of American- or Taiwanese-made science documentaries. The lectures ended on a positive note, emphasising that by changing one's diet one could not only improve one's own health but help resolve wider issues.

The format of the lectures at Sino-Agriculture - beginning with individual health and expanding outwards - was similar to that of the Buddhist vegetarian pamphlets circulated in several vegetarian restaurants. In these texts messages of karmic retribution and the protection of life were more frequent and explicit than in the Sino-Agriculture lectures, but 
like the latter scientific arguments about nutrition, environment, animal welfare and food security were prominent in the pamphlets.

Participants did not always accept Sino-Agriculture's messages. They used the seminars as opportunities to engage with their own concerns about the food supply and to discuss how best to cope with it. In some cases participants appeared more comfortable with explicitly Buddhist messages than did the seminar leaders. One lecture I attended included the argument that eating meat not only exacerbated global warming but was also the cause of a perceived world-wide increase of earthquakes, tsunamis and other disasters. When I asked about this claim during the discussion two of the audience members, but not the lecturer, clarified it in terms of Buddhist ideas of karmic retribution.

Another lecture I attended was for parents and grandparents of children in the Confucian classics class and was entitled 'Change diets, save the planet' (Gaibian yinshi jiu diqiu). In the discussion, participants seemed to agree with the lecturer that the taste and healthiness of meat had deteriorated, and that people were now eating too much meat. Many connected these developments with broader declines in social morality and health. One grandfather even claimed that Chairman Mao should be regarded as the saviour of the Chinese people for keeping them so poor that they could not afford to eat meat.

Others rejected the vegetarian message. One elderly man boasted of his capacity for meat, and claimed that 'Vegetarian food is grub for Shaolin monks, not for me!' (Apparently the man was unaware, as was I until a reviewer pointed it out, that according to a well-known legend Shaolin monks were exempted from vegetarianism by a Tang Dynasty $\left(7^{\text {th }}-10^{\text {th }}\right.$ centuries) emperor.) He went on to make the point, in contrast to the other grandfather, that he wasn't going to back to eating the maize that he had to subsist on growing up in the impoverished countryside. 
One point of disagreement at the seminar concerned the suitability of vegetarian diets for different family members. One person maintained that elderly household members would not get enough nutrients if they did not eat meat, while another claimed that her elderly father had become healthier after he had become a Buddhist and made a vow to abstain from animal flesh. Several parents made the point that children required animal protein to grow, and would not be convinced by the teacher's insistence that they did not.

Towards the end of the discussion the teacher summarised the main points of her lecture and repeated the claim that we could save the planet by becoming vegetarians. This was politely ignored by the audience, while one parent's suggestion that we should all agree to eat 'a little less meat' received a resounding round of applause.

\section{Being Vegetarian in Kunming}

Vegetarianism was described by some Kunmingers as 'fashionable' (shimao). Yet it is clear from the seminar discussed in the previous section that meat-eating remained central to mainstream Kunming foodways. Opinions differed with regards to the extent to which Kunmingers had become tolerant of others' vegetarianism. Ms Chen, a devout Buddhist in her late twenties, claimed that ordinary people were now increasingly prepared to accept vegetarianism. Ms Jia, a woman of similar age who had several vegetarian friends, argued that most Kunmingers could not understand why anyone who was not a Buddhist would give up meat. She complained about the lack of vegetarian restaurant options in the city compared to Beijing, and explained that if she visited ordinary restaurants in Kunming with vegetarian friends staff would insist that vegetables cooked in chicken stock or with pieces of meat were 'vegetarian'.

Despite the 'fashion' for vegetarianism and although the vegetarian restaurants created new spaces for meat-free commensality, observing a vegetarian diet in Kunming was 
not always easy. For some Kunmingers, as I discuss in this section, the new vegetarian restaurants played a part in shaping and strengthening their commitments to vegetarianism. By their own accounts, the restaurants encouraged them to connect their individual concerns about health with wider issues and helped them to observe a vegetarian diet.

Mr Miao was a hospital consultant in his sixties. In 2009 he committed to maintaining a vegetarian diet for ten days each month. He often ate at Xianghaiyue, which was near his home. Sometimes he would buy food at the restaurant and bring it home. That way he could have his own meal but still eat together with his family. Mr Miao claimed that he was not a Buddhist, but that he had first turned to this new dietary regime in response to problems with gout (tongfeng). However, he spent time reading the vegetarian literature and talking with staff, and had become increasingly concerned with the effects of meat production on the environment, especially global warming. Moreover, he was becoming uneasy with the idea of taking animal lives for meat, using the Buddhist term shasheng. By his own account, then, Mr Miao had turned to vegetarianism because of concerns with his health, and had subsequently, following visits to vegetarian restaurants, come to articulate vegetarian practice with an ethical concern for animals and for the global environment. However, Mr Miao eventually gave up his vegetarian commitments. He explained this in terms of issues of commensality, noting that his meat avoidance was 'impractical' (bu fangbian) for his family.

Mr Zhang was in his thirties and ran a small travel agency together with his wife and brother. He had started attending Sino-Agriculture's classes because of dizzy spells and other health issues. When I first met him in 2008 he endorsed the message of organic farming and was convinced that his health troubles had to do with 'pollutants' (wuran) in the foods he ate. However, he said he 'could not accept' (bu neng jieshou) vegetarianism, nor could he afford to eat at the restaurant. By 2009, however, the family business was doing well. He and his wife had become active members, and they were planning to send their son to Confucian 
classics lessons. They had also become regular visitors at the vegetarian restaurant. Zhang now preferred vegetarian food, though he ate meat with business associates and guests. Zhang and his family were upwardly mobile migrants from the countryside. He was proud that his ability to speak standard Mandarin concealed his rural origins, and the family's partial 'conversion' to vegetarianism at Sino-Agriculture was arguably tied to their middleclass aspirations.

Like his wife Ms Chen (mentioned above in this section), Mr Tao, a research student in economics, was a devout lay Buddhist. He believed that vegetarianism was meritorious, but also something one could be flexible about. He liked eating meat sometimes, and would not turn down meat when visiting his family in rural Hunan, because he recognised that for people in the countryside serving meat was an expression of their feelings for him. He justified this flexibility referring to the teachings of Master Jingkong, a famous overseasbased Chinese monk. Nevertheless, Tao wanted to become gradually more vegetarian. He liked the food, atmosphere and serious Buddhism of Green Garden, and felt that this restaurant could help him deepen his commitment to vegetarianism.

\section{Chinese Buddhism and Voluntary Vegetarianism}

Similar to accounts of vegetarian movements in Western settings, activistentrepreneurs in Kunming encouraged people to adopt vegetarian diets in response to their anxieties about food safety and health in the context of the growing industrialisation of meat production, and subsequently sought to instil a commitment to vegetarianism based not only on bodily health and wellbeing but also on ethical commitments to issues such as animal welfare, environmental protection or global food security. Moreover, as in Western contexts Kunming's vegetarian restaurants and shops constituted an infrastructure that facilitated commitments to vegetarian diets by providing both meat-free foods and settings where 
vegetarians could gather and discuss common interests in a society where meat was central to dominant forms of cuisine and commensality.

But there were also culturally specific dimensions to Kunming's vegetarianism that complicate a Western-based understanding of vegetarian movements. The central role played by Buddhism in Kunming's vegetarian restaurants distinguished it both from most Western vegetarian movements and also from other ethical food groups in Kunming, such as those operating direct marketing schemes (Klein 2014). Alongside secular languages of nutritional health or global warming, Buddhist notions of karmic merit, compassion, and the protection of life permeated the pamphlets, seminars and informal discussions held at Buddhist vegetarian restaurants, despite restrictions on religious proselytising. In articulating people's anxieties about the dangers of excessive consumption and industrial meat with the karmic consequences of taking life Buddhist vegetarian groups were actively encouraging reengagement with a moral understanding of meat-eating that was once deeply embedded in Chinese society and which stood in contrast to the secular, pro-meat ideologies of modern Chinese states.

The significance of Buddhism in Kunming's vegetarian movement had to do not only with religious and moral values, but also with the ways in which activists positioned themselves in relation to wider society. Cao Wenbin (2010: 94-96, 103-104) highlights the non-confrontational, accommodating approach to vegetarian conversion taken by Chinese Buddhists, which relies on the aesthetics of vegetarian cuisine and the popularisation of periodic purity laws. This approach was evident among Kunming's vegetarian restaurateurs, who offered a creative range of vegetarian meals and encouraged customers to make voluntary, periodic commitments to a meat-free diet. This approach was also reflected in the vegetarian biographies of Tao, Miao and Zhang, all of whom - including Tao, an active Buddhist - took a highly situational attitude to meat avoidance, and in the Sino-Agriculture 
seminar I described, where free reign was given to participants' divergent views on meateating.

In Britain and the United States, the successes of the vegetarian movement and food industries have contributed to an increasing 'mainstreaming' of vegetarianism. Still, adopters of vegetarian diets often continue to be regarded as culturally marginal, and have to carefully negotiate their dietary choices with dominant practices (Boyle 2011), while the growing number of openly 'flexible' vegetarians has produced rifts within the vegetarian movement. In Kunming, by contrast, 'flexitarianism' was central to both the pedagogical practice of activists and the understanding of vegetarianism among non-activists. This flexibility built on longstanding cultural attempts to negotiate a balance between the moral unease surrounding meat-eating and the moral reprehension of complete vegetarianism for all but the clergy. In Kunming, strict vegetarianism threatened to undermine familial and social ties, but periodic observances of meat-free diets, particularly in the context of religious commitments, was a culturally understood practice, if not always easy to negotiate.

Cao (2010:61-104) argues that Buddhism ultimately provides a firmer foundation for vegetarianism than animal liberation philosophy, but that its non-confrontational approach, though suited to Chinese political realities and social values, has proven much less successful in spreading vegetarianism in China than have the more strident methods of animal liberation and other vegetarian activists in the West. What, then, is the potential for a further popularisation of voluntary vegetarianism in urban China? Apart from an increased interest in Buddhism, one possibility lies in the ways Buddhist vegetarian restaurants actively appeal to middle-class projects of self-cultivation for example through food, ambiance, moral education for children and an engagement with scientific and Western vegetarian discourses. A further popularity of vegetarian foods among the urban middle class could contribute to the entrenchment of social hierarchies by consolidating them in class-based cultural differences, 
but it could also come to pose a serious challenge to the powerful associations in China of meat-eating with social status, success and progress.

\section{Acknowledgements}

Fieldwork in Kunming was supported by the British Academy (SG-43053, SG-50545 and SG-111559). I am grateful to Miao Yun for her research assistance in 2008 and 2009, to $\mathrm{Xu}$ Chenjia for sharing her research on food and sociocultural change for FCRN's report on China's food system (Garnett \& Wilkes 2014: 91-97), to Nir Avieli whose work on Buddhist vegetarian restaurants in Vietnam (2014) inspired me to write this piece, and to James Staples and three anonymous reviewers for their very helpful comments and suggestions.

\section{References}

Anderson, E.N. 1988. The Food of China. New Haven, CT: Yale University Press. Ash, Robert Fairbanks. 2006. Population Change and Food Security in China. In Critical Issues in Contemporary China, edited by Czeslaw Tubilewicz, pp. 143-66. New York: Routledge.

Ashiwa, Yoshiko and David L. Wank. 2005. The Globalization of Chinese Buddhism: Clergy and Devotee Networks in the Twentieth Century. International Journal of Asian Studies, 2(2): 217-237.

Ashley, Bob, Joanne Hollows, Steve Jones and Ben Taylor. 2004. Food and Cultural Studies. London and New York: Routledge.

Avieli, Nir. 2014. Vegetarian Ethics and Politics in Late-Socialist Vietnam. In Ethical Eating in the Postsocialist and Socialist World, edited by Yuson Jung, Jakob A. Klein and Melissa L. Caldwell, pp. 144-166. Berkeley: University of California Press.

Beardsworth, Alan and Teresa Keil. 1997. Sociology on the Menu: An Invitation to the Study 
of Food and Society. London: Routledge.

Belasco, Warren. 2005. Food and the Counterculture: A Story of Bread and Politics. In The Cultural Politics of Food and Eating: A Reader, edited by James L. Watson and Melissa L. Caldwell, pp. 217-234. Oxford: Blackwell.

Boyle, Joseph E. 2011. Becoming Vegetarian: The Eating Patterns and Accounts of Newly Practicing Vegetarians. Food \& Foodways, 19(4): 314-333.

Cao Wenbin. 2010. Xifang Dongwu Jiefang Lun yu Zhongguo Fojiao Hushengguan Bijiao Yanjiu (A Comparative Study of Western Animal Liberation and Chinese Buddhist Notions of the Protection of Life). Beijing: Renmin Chubanshe.

Chen Hongbing. 2009. Shengtai Huanbao yu Fojiao Sushiguan de Kuozhan (Ecological Protection and the Expansion of Buddhist Vegetarianism). Wutaishan Yanjiu, 2: 59-63. Clark, Dylan. 2004. The Raw and the Rotten: Punk Cuisine. Ethnology, 43(1): 19-31.

FAO. 2009. The State of Food and Agriculture: Livestock in the Balance. Rome: Food and Agriculture Organization of the United Nations.

Fan, Lizhu, Evelyn Eaton Whitehead and James D. Whitehead. 2005. The Spiritual Search in Shenzhen: Adopting and Adapting China's Common Spiritual Heritage. Nova Religio, 9 (2): 50-61.

Farquhar, Judith. 2002. Appetites: Food and Sex in Postsocialist China. Durham, NC: Duke University Press.

Fiddes, Nick. 1991. Meat: A Natural Symbol. London: Routledge.

Gale, Fred and Kuo Huang. 2007. Demand for Food Quantity and Quality in China. Economic Research Report 32. Economic Research Service, United States Department of Agriculture. Available at: <www.ers.usda.gov/publications/err32/> Garnett, Tara \& Andreas Wilkes. 2014. Appetite for Change: Social, Economic and Environmental Transformation in China's Food System. Food Climate Research 
Network.

Gillette, Maris Boyd. 2000. Children's Food and Islamic Dietary Restrictions in Xi'an. In Feeding China's Little Emperors: Food, Children, and Social Change, edited by Jun Jing, pp. 71-93. Stanford, CA: Stanford University Press.

Goossaert, Vincent. 2005a. The Beef Taboo and the Sacrificial Structure of Late Imperial Chinese Society. In Of Tripod and Palate: Food, Politics, and Religion in Traditional China, edited by Roel Sterckx. pp. 237-248. New York: Palgrave Macmillan.

Goosaert, Vincent. 2005b. L'interdit du bof en Chine. Agriculture, étique et sacrifice. Bibliotèque de l'institut des Hautes Études Chinoises, Volume XXXIV. Paris: Collège de France.

Goossaert, Vincent and David A. Palmer. 2011. The Religious Question in Modern China. Chicago: The University of Chicago Press.

Guo Geng. 2003. Wo Xing Wo Su - Yi Ge Huanbaozhe de Sushi Liyou (My Way: An Environmentalist's Reasons for Being Vegetarian). Shuzhai, 12: 64-67.

Handlin Smith, Joanna F. 1999. Liberating Animals in Ming-Qing China: Buddhist Inspiration and Elite Imagination. The Journal of Asian Studies, 58(1): 51-84.

Ji, Zhe. 2011. Buddhism in the Reform Era: A Secularized Revival? In Religion in Contemporary China: Revitalization and Innovation, edited by Adam Yuet Chau, pp. 32-52. London: Routledge.

Kieschnick, John. 2005. Buddhist Vegetarianism in China. In Of Tripod and Palate: Food, Politics, and Religion in Traditional China, edited by Roel Sterckx, pp. 186-212. New York: Palgrave Macmillan.

Klein, Jakob A. 2008. Afterword: Comparing Vegetarianisms. In Food: Memory, Pleasure and Politics, edited by Caroline Osella \& Filippo Osella. Special Issue of South Asia: Journal of South Asian Studies, 31(1): 199-212. 
Klein, Jakob A. 2013a. Everyday Approaches to Food Safety in Kunming. The China Quarterly, 214: 376-93.

Klein, Jakob A. 2013b. 'There is No Such Thing as Dian Cuisine!' Food and Local Identity in Urban Southwest China. Food and History, 11(1): 203-225.

Klein, Jakob A. 2014. Connecting with the Countryside? 'Alternative' Food Movements with Chinese Characteristics. In Ethical Eating in the Postsocialist and Socialist World, edited by Yuson Jung, Jakob A. Klein and Melissa L. Caldwell, pp.116-143. Berkeley: University of California Press.

Kleinman, Arthur, Yunxiang Yan, Jing Jun, Sing Lee, Everett Zhang, Pan Tianshu, Wu Fei \& Guo Jinhua. 2012. Deep China: The Moral Life of the Person, What Anthropology and Psychiatry Tell Us About China Today. Berkeley: University of California Press.

Marsh, Sarah \& Thomas Hale. 2012. New Age Vegetarians. Chinadaily.com.cn (21 October). Available at: http://www.chinadaily.com.cn/sundays/2012-10/21/content_15834323.htm

Maurer, Donna. 2002. Vegetarianism: Movement or Moment? Philadelphia, PA: Temple University Press.

Morris, Carol \& James Kirwan. 2012. Vegetarians: Uninvited, Uncomfortable or Special Guests at the Table of the Alternative Food Economy. In Taking Food Public: Redefining Foodways in a Changing World, edited by Psyche Williams-Forson \& Carole Counihan, pp.542-560. New York: Routledge.

Nelson, Craig. 2011. After Food Scandals, Growing Number of Chinese Reject Meat for Vegetarianism. The National (31 May). Available at: http://www.thenational.ae/news/world/asia-pacific/after-food-scandals-growingnumber-of-chinese-reject-meat-for-vegetarianism

Oxfeld, Ellen. 2014. The Moral Significance of Food in Reform-Era Rural China. In Ethical 
Eating in the Postsocialist and Socialist World, edited by Yuson Jung, Jakob A. Klein and Melissa L. Caldwell, pp. 44-68. Berkeley: University of California Press.

Schneider, Mindi. 2011. Feeding China's Pigs: Implications for the Environment, China's Smallholder Farms and Food Security. Institute for Agriculture and Trade Policy. Available at: < http://www.iatp.org/files/2011_04_25_FeedingChinasPigs_0.pdf>

Shi Youbo. 2004. Sushizhuyi (Vegetarianism). Beijing: Beijing Tushuguan Chubanshe.

Stuart, Tristram. 2006. The Bloodless Revolution: Radical Vegetarians and the Discovery of India. London: Harper Press.

Tang, Yuankai. 2008. Eat Without Meat. Beijing Review (May): 19.

Thompson, Stuart E. 1988. Death, Food and Fertility. In Death Ritual in Late Imperial and Modern China, edited by James L. Watson and Evelyn S. Rawski, pp.71-108. Berkeley: University of California Press.

Twigg, Julia. 1983. Vegetarianism and the Meanings of Meat. In The Sociology of Food and Eating, edited by Anne Murcott, pp.18-30. Aldershot, Hants: Gower Publishing Company Ltd.

Valeri, Valerio. 2000. The Forest of Taboos: Morality, Hunting, and Identity among the Huaulu of the Moluccas. Madison: University of Wisconsin Press.

Watson, James L. 2014. Meat: A Cultural Biography in (South) China. In Food Consumption in Global Perspective: Essays in the Anthropology of Food in Honour of Jack Goody, edited by Jakob A. Klein and Anne Murcott, pp.25-44. New York: Palgrave Macmillan.

Weller, Robert P. 2006. Discovering Nature: Globalization and Environmental Culture in China and Taiwan. Cambridge: Cambridge University Press.

Xu Changwen \& Xu Jing. 2007. Jiexi Fojiao de Dongwu Quanli Sixiang (An Analysis of Thought on Animal Rights in Buddhism). Lanzhou Xuekan, 9: 95-97. 
Yan, Yunxiang. 2012. Food Safety and Social Risk in Contemporary China. The Journal of Asian Studies, 71(3): 705-729.

Yang Shuqun. 2006. Lao Kunming Fengqing Lu (Record of the Customs of Old Kunming). Kunming: Yunnan Minzu Chubanshe.

Zhan, Mei. 2008. Wild Consumption: Relocating Responsibilities in the Time of SARS. In Privatizing China: Socialism from Afar, edited by in Li Zhang and Aihwa Ong, pp.151-167. Ithaca, NY: Cornell University Press.

Zhang, Li. 2008. Private Homes, Distinct Lifestyles: Performing a New Middle Class. In Privatizing China: Socialism from Afar, edited by in Li Zhang and Aihwa Ong, pp.23-40. Ithaca, NY: Cornell University Press.

Zhang, Li \& Aihwa Ong (eds). 2008. Privatizing China: Socialism from Afar. Ithaca, NY: Cornell University Press. 